RASĀYAN J. Chem.

Vol. 13 | No. 3 |1767-1776| July - September | 2020 ISSN: 0974-1496 | e-ISSN: 0976-0083 | CODEN: RJCABP

\title{
PREPARATION AND CHARACTERIZATION OF CELLULOSE PULP FROM FIBER OF DURIAN PEEL
}

\author{
Rosliana Lubis $^{1,2}$, Basuki Wirjosentono ${ }^{3 *}$ Eddiyanto $^{3,4}$ \\ and Athanasia Amanda Septevani ${ }^{5}$ \\ ${ }^{1}$ Postgraduate School, Department of Chemistry, Faculty of Mathematics and Natural Sciences, \\ Universitas Sumatera Utara, J1. Bioteknologi No.1, Medan 20155, Indonesia \\ ${ }^{2}$ Department of Sains dan Teknologi, Universitas Medan Area, Sumatera Utara, Indonesia \\ ${ }^{3}$ Department of Chemistry, Faculty of Mathematics and Natural Sciences, Universitas Sumatera \\ Utara, Jl. Bioteknologi No.1, Medan 20155, Indonesia \\ ${ }^{4}$ Department of Chemistry, Faculty of Mathematics and Natural Sciences, Universitas Negeri \\ Medan, Sumatera Utara, Indonesia \\ ${ }^{5}$ Research Center for Chemistry, Indonesian Institute of Sciences, Jakarta, Indonesia \\ *E-mail: basuki@usu.ac.id
}

\begin{abstract}
Cellulose pulp is a biomolecule that obtained as a bundle of lignocellulose fiber. Durian peel is one of the most agricultural wastes that can be found in one province of Indonesia. This study aimed to prepare cellulose pulp from durian peel fiber. The separation of bundle durian peel fibre was performed using the grinding method. The extraction process is the most important step due to during this process any unwanted materials (hemicellulose, lignin, etc) can be removed from the cellulose matrix. The extraction was performed by using a chemical treatment that combined with steam explotion. The yield of cellulose pulp obtained by this process was about $40-45 \%$. Cellulose pulp was categorized as short fiber or lead bleached craft pulp. Bright degree, extractive content (dichloromethane), and water content meet the minimum value of SNI 6107. The morphological analysis of durian cellulose pulp showed a smooth surface with pores in several places. The crystallinity index of cellulose pulp durian after treatment was an increase to $60.67 \%$ from $40.07 \%$.
\end{abstract}

Keywords: Cellulose Pulp, Durian Peel, Fiber, Extraction, Lignocellulose

(C) RASĀYAN. All rights reserved

\section{INTRODUCTION}

The pulp is also called cellulose and starting material for several kinds in the industrial process, i.e. paper, composite materials, a derivate of cellulose (e.g. viscose rayon, cellulose ester, cellulose ether) and other cellulose-based products (Nano- and microcrystalline cellulose). ${ }^{1,2}$

The wide application of cellulose in the industrial level makes cellulose to be an interesting natural product for characterizing and developing. Silviana and Subagio, ${ }^{3}$ made cellulose-based bioplastic from bamboo fiber. Siregar.et.al, ${ }^{4}$ reported a successfully of cellulose-based biofilm preparation, with antibacterial activity, that isolated from Gebang leave (Coryphautan). The obtained biofilm was prepared through a crosslinked process between modified cellulose (CMC) and PVA. In other study, Mahendra et. al ${ }^{5}$ reported oil palm-based nanocrystal cellulose can be used as co-agent to help the emulsification of cyclic natural rubber. Also, Zeng et.al, ${ }^{6}$ reported, cellulose that obtained from corn stem can be modified with acrylonitrile, and it can act as an adsorbent for heavy metal, i.e. cadmium. Another study also performed to develop a specific adsorbent for lead, modifying cellulose with benothiazole. ${ }^{7}$

The raw material of cellulose pulp mostly dominated by wood-based products, i.e. short and long wood fiber. The percentage of wood and non-wood-based cellulose pulp is about $90-95$ and $10-5 \%$, respectively. This data showed the dependence on the wood-based product, the impact of this activity is deforestation and replanting. Thus, the alternative raw material form a non-wood-based product is urgently needed ${ }^{8,}{ }^{8}$ Durian peel waste is 
RASĀYAN J. Chem.

Vol. 13 | No. 3 |1767-1776| July - September | 2020

one potential alternative to substitute wood-based cellulose pulp. The use of durian peel waste for cellulose pulp production is believed can reduce the cost production and improve the value of durian fruit itself.

Durian peel is categorized as waste from the agriculture sector and has a high potential to develop as fiber sources. This based on its availability - Statistics Indonesia claimed the production of durian fruit in Sumatera Utara was an increase from 65529 (the year 2015) to 74811 tons (the year 2017). This number is predicted will continue to increase to meet markets need for the next 20 years, it's about 90000 ton/year ${ }^{10}$. The increase in production numbers will have a direct impact on the waste number that will be produced. The waste from durian can be classified into the seed (20-25\%) and peel (70-85\%). This percentage showed that durian has a quite high organic waste. ${ }^{3,11,12,13}$ Based on its chemical composition, durian contained by cellulose $(60.45 \%)$, hemicellulose $(13.09 \%)$, and lignin $(15.45 \%){ }^{11,12,14}$

The pulp can be used for starting material for any products after passes the extraction step. This process is needed to remove any impurities attached to cellulose pulp surfaces, i.e. lignin and hemicellulose (Fig.-1). In the plant tissue, cellulose can be found together with starch, lignin and hemicellulose.

Several studies on the cellulose pulp extraction of durian peel have been done. Rachtanapun et $\mathrm{al}^{14}{ }^{14}$ had performed the extraction in the presence of $10 \mathrm{w} . \% \mathrm{NaOH}$ at $100^{\circ} \mathrm{C}$ and followed by the bleaching process using hydrogen peroxide. ${ }^{11}$ had done the extraction of durian peel powder, and the extraction was conducted using chlorination and maceration. Dewi and Putri ${ }^{10}$ had successfully isolated cellulose from durian peel. Those studies isolate the cellulose directly without any treatment of fiber separation.

The objective of this study was to prepare pulp from durian peel waste. The first treatment was fiber separation using a mechanical technique. The obtained fiber was continued by the pulping process in the combination of hydrolysis $\left(\mathrm{HNO}_{3}\right.$ solution), alkalization $\left(\mathrm{NaOH}\right.$ solution at $\left.70^{\circ} \mathrm{C}\right)$, and bleaching in the presence of $\mathrm{NaOCl} 1.75 \mathrm{wt} \%$. Acid hydrolysis is performed to remove the presence of starch, wax, and fatty acid in the durian fiber ${ }^{15,16,17}$. Then the alkalization is conducted to remove lignin and hemicellulose that bent with cellulose. ${ }^{18-20}$

\section{EXPERIMENTAL}

Material and Methods

Durian peel waste was obtained from the traditional market in Binjai, Sumatera Indonesia, Indonesia. Chemical in this study was pro analytical grade from Merck, i.e. nitric acid, sodium hydroxide, sodium perchlorate, sodium hypochlorite, hydrogen peroxide, and sodium meta periodate.

\section{Fiber Separation of Durian Peel Waste}

The separation of durian peel fiber was performed mechanically, based on our previous study. ${ }^{21}$ Durian peel waste was washed several times to remove any contamination on its surface. The dried peel was continued with the grinding process and soaked in water for $24 \mathrm{~h}$. The soaking treatment was performed for removing the gum from the durian surface through the microbial process (Fig.-2c).

\section{Cellulose Pulp Preparation}

$75 \mathrm{~g}$ of fiber was added into $1000 \mathrm{~mL}$ of $\mathrm{HNO}_{3} 3.5 \mathrm{wt} . \%$ and placed in the autoclave. The steam explosion was conducted for $30 \mathrm{~min}\left(126^{\circ} \mathrm{C}\right.$ and $\left.0.15 \mathrm{MPa}\right)$. The obtained fiber then neutralized using distillate water, and the fiber was refluxed with $750 \mathrm{~mL}$ of $\mathrm{NaOH} 2 \mathrm{wt} . \%$ at $70-80^{\circ} \mathrm{C}$ for $30 \mathrm{~min}$. Treatment was continued by the bleaching process using $\mathrm{NaOCl} 1.75 \mathrm{wt} . \%$ at $70-80^{\circ} \mathrm{C}$ for $30 \mathrm{~min}$. The obtained cellulose was continued into alkalization using $500 \mathrm{~mL}$ of $\mathrm{NaOH} 17.5 \mathrm{wt} . \%$ for obtaining $\alpha$-cellulose and then neutralized using distillate water. The obtained $\alpha$-cellulose was bleached using $500 \mathrm{~mL}$ hydrogen peroxide $10 \%$ at $70^{\circ}-80^{\circ} \mathrm{C}$ for $30 \mathrm{~min}$ and washed with distillate water to remove the scent of hydrogen peroxide.

\section{Cellulose Pulp casting}

The casting of pulp was performed using a hand sheet (Fig.-1). About $200 \mathrm{~g}$ of wet cellulose pulp was dispersed in $2000 \mathrm{~mL}$ distillate water. The obtained solution was poured into the hand sheet and dried using a vacuum system (the final weight of cellulose pulp was 84-88 g) (Fig.-2f).

\section{Analysis of Cellulose Pulp}

The obtained cellulose pulp was analyzed using several methods based on the Indonesian National Standard (SNI): 
RASĀYAN J. Chem.

Vol. 13 | No. 3 |1767-1776| July - September | 2020

SNI 01-1840-1990 to measure the length of fiber from wood and non-wood.

SNI ISO 5264-1, Pulp - beating process in the laboratory - Part 1: Valley beater method.

SNI ISO 5267-2, Pulp - determination of drain ability - Part 2: Canadian Standard Freeness method.

SNI ISO 2470-1, Paper, board, and pulp - Measurement of diffuse blue reflectance factor - Part 1: indoor daylight condition (ISO brightness).

SNI ISO 5350-3, Pulp - specifies a procedure for the estimation of the visible dirt and shaves by reflected light using the Equivalent Black Area (EBA) method in pulps.

SNI 8401, Soluble extractive of wood and pulp (T-2014 cm-07, IDT)

SNI ISO 52691, Pulp - procedure for sheet preparation for physical testing - Part 1: Conventional method SNI 08-7070, Procedure to determine the water content of pulp and wood using the oven method.

SNI ISO 536 Paper and board - Procedure for determining the grammage of paper and board

SNI ISO 1974 Specifies a method for determining the (out-of-plane) tearing resistance of paper Elmendorf method

SNI ISO 2758, Specifies a method for measuring the bursting strength of paper

SNI ISO 1924-2, Specifies a method for measuring the tensile properties - Part 2: Constant rate of elongation method.

\section{FT-IR Analysis}

The spectra of the functional group on cellulose pulp and modified cellulose pulp was determined by the FT-IR spectrophotometer using Cary 630 FT-IR Agilent. All obtained spectrum was recorded in the following condition: the resolution of $4 \mathrm{~cm}^{-1}$ and wavenumber range of $4000-650 \mathrm{~cm}^{-1}$ and scanned 32 times.

\section{SEM Analysis}

The surface morphology characterization of cellulose and modified cellulose were determined using a scanning electron microscope (SEM) JEOL/EO JSM-6510LA Version 1.0.

\section{XRD Analysis}

The XRD analysis was performed using Lab X XRD-6100 (Shimadzu) with the following condition: voltage of $40 \mathrm{kV}$, current of $30 \mathrm{~mA}$ and $\mathrm{CuK} \alpha$ radiation. The scan process was performed in the range of $2 \theta 7-70^{\circ}$. Crystallinity index was determined using equation (1) below:

$$
I_{c r}=\frac{I_{002}-I_{a m}}{I_{002}} \times 100 \%
$$

Where, $\mathrm{I}_{\mathrm{cr}}, \mathrm{I}_{002}$, and $\mathrm{I}_{\mathrm{am}}$, referred to the crystallinity index, the intensity of the crystalline region $\left(22^{\circ}\right)$, and intensity of amorphous region $\left(18^{\circ}\right) .{ }^{22-28}$

\section{Thermal Analysis}

Thermogravimetric (TG) and differential thermogravimetric analysis (DTA) was performed using Extra TGDTA7300 (Hitachi). The measurement temperature was set from room temperature until $600^{\circ} \mathrm{C}$ with heat rate $10^{\circ} \mathrm{C} /$ minute.

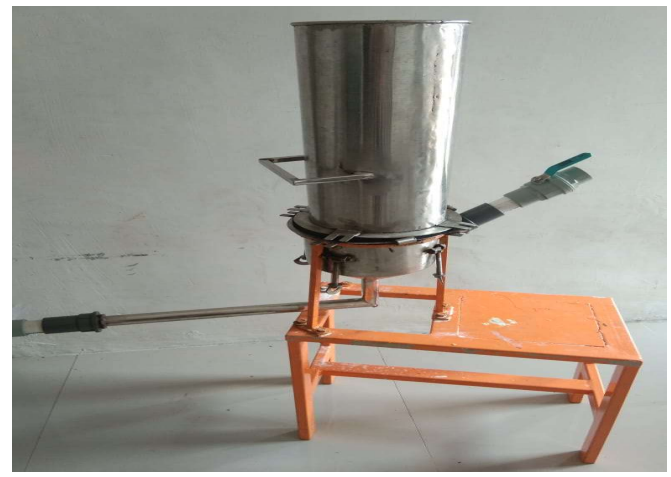

Fig.-1: Hand Sheet for Cellulose Pulp Casting 1769 
RASĀYAN J. Chem.

Vol. 13 | No. 3 |1767-1776| July - September | 2020

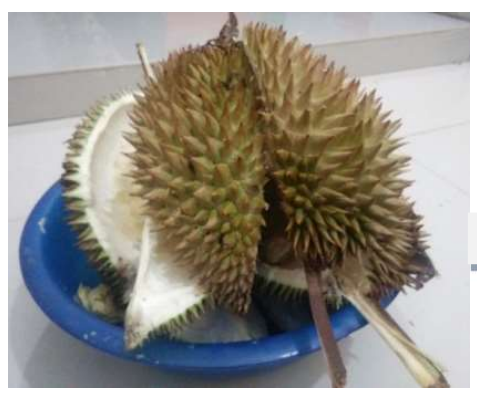

(a)

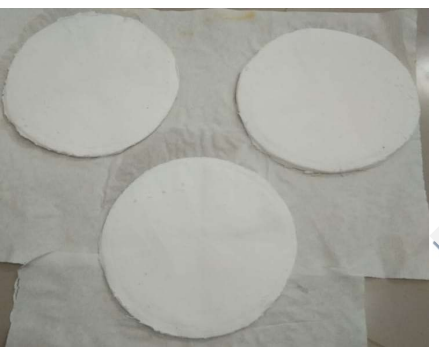

(f)

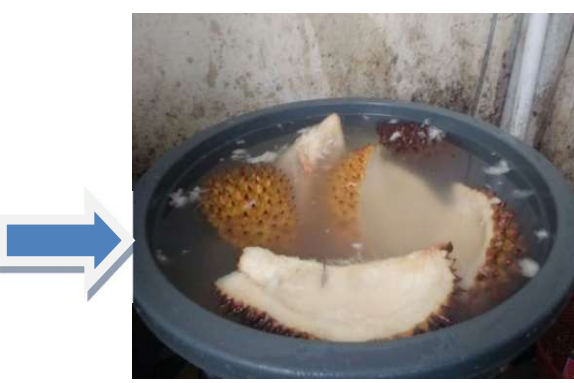

(b)

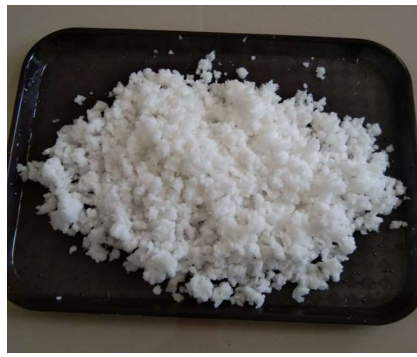

(e)

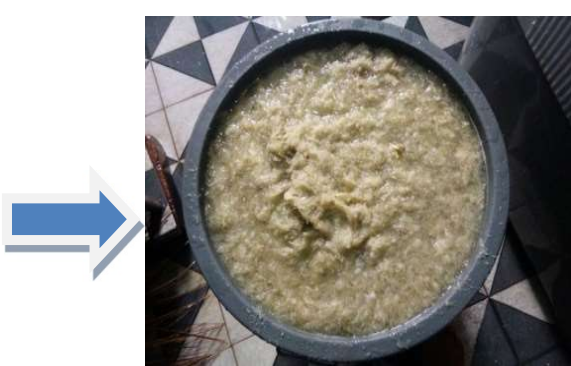

(c)

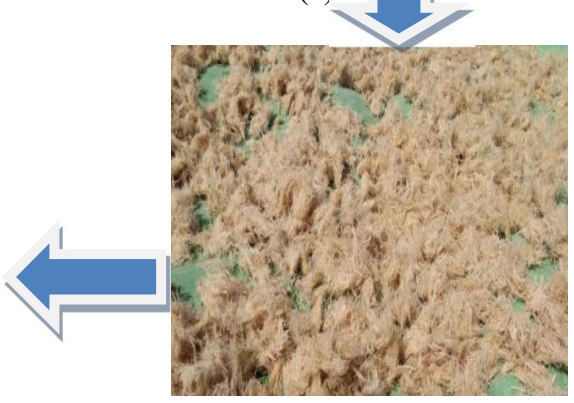

(d)

Fig.-2: Pulp Preparation, (a) Durian Peel, (b) Soaked Durian Peel, (c) Soaked Durian Peel after Grating, (d) Dried Durian Peel Fiber, (e) Cellulose Pulp, and (f) Casted Cellulose Pulp

\section{Cellulose Pulp}

\section{RESULTS AND DISCUSSION}

Cellulose is a natural biopolymer that can be extracted from any kind of lignocellulose sources. The presence of cellulose in nature can be found as a matrix that cross-linked with any kind of polysaccharide. The most component of that matrix is cellulose, hemicellulose, and lignin. ${ }^{29}$. Cellulose extraction from that matrix was performed to remove those unwanted components. Figure-2 shows the process for separating cellulose from those unwanted components (hemicellulose, lignin and extractive components). The process was started by soaking the peel durian fiber in water to remove any dirt on the surfaces of peels (Fig.-2b). The process was continued by the grinding process and soaking again in water for $24 \mathrm{~h}$ (Fig.-2c). The drying process was performed to remove any water that absorbed by peels (Fig.-2d). And at Fig.-2e, cellulose pulp was obtained from peels fiber after the pulping process through the hydrolysis process, alkalization, and bleaching. The casting of cellulose pulp was performed by a conventional technique using a hand sheet (ISO 5269-1:2005). The yield of cellulose pulp obtained through this process was about $40-45 \%$. The result can vary depends on the method that used, for example in the study performed by Penjumras, et,al, ${ }^{11}$, at the end of the process the yield was about $33,12 \%$.

\section{Characteristic of Cellulose Pulp}

The testing to determine of fiber length was performed following SNI 0698 NBKP (Needle Bleached Kraft Pulp). Needle Bleached Kraft Pulp is produced form length wood-fiber and the minimum value was determined must be $2.1 \mathrm{~mm}$. Table 1 showed the obtained pulp has a lower value than minimum value that needed to meet based on the SNI 0698 NBKP. Based on that value, the obtained pulp can be categorized as short fiber.

Table-1: Fiber Length of Durian Peel

\begin{tabular}{c|c|c|c|c}
\hline No. & Parameter & Unit & Result & SNI 0698 NBKP \\
\hline 1 & Average fiber length & $\mathrm{mm}$ & 0,67 & $\min .2,1$ \\
\hline
\end{tabular}


RASĀYAN J. Chem.

Vol. 13 | No. 3 |1767-1776| July - September | 2020

The obtained cellulose pulp was then compared with the SNI 6107 LBKP (Leaf Bleached Kraft Pulp). The data were summarized in Table-2. Based on those parameters, durian peel pulp meets 5 of 8 parameters, i.e. the brightness degree has a higher value than the SNI 6107, this is due to the impact of the bleaching process using $\mathrm{NaOCl}$ and hydrogen peroxide during the pulp preparation. But the contrary result was found on the visible dirt parameter (Fig.-3), this value quite high than the maximal value that needed to be meet. This result can be caused by completing treatment during the hydrolysis and alkalization.

Tabel-2: The Quality of Durian Peel Cellulose Pulp

\begin{tabular}{c|c|c|c|c}
\hline No. & Parameter & Unit & Result & SNI 6107 LBKP \\
\hline 1 & Degree of Initial Beating & $\mathrm{mL} \mathrm{CSF}$ & 540 & min. 430 \\
\hline 2 & Degree of Brightness & $\%$ ISO & 91 & min. 85 \\
\hline 3 & Visible Dirt & $\mathrm{mm}^{2} / \mathrm{m}^{2}$ & 89 & max. 0.4 \\
\hline 4 & $\begin{array}{c}\text { Extractive Content } \\
\text { (Dichloromethane) }\end{array}$ & $\%$ & 0.3 & max. 10 \\
\hline 5 & Water Content (AD) & $\%$ & 7 & min. 5.5 \\
\hline 6 & $\begin{array}{c}\text { Tearing Index with eating } \\
\text { degree of 300 ml CSF }\end{array}$ & $\mathrm{mNm}^{2} / \mathrm{g}$ & 2.8 & min. 2.5 \\
\hline 7 & $\begin{array}{c}\text { Bursting Index with beating } \\
\text { degree of 300 ml CSF }\end{array}$ & $\mathrm{kPa} \mathrm{m} / \mathrm{g}$ & 0.3 & min. 45 \\
\hline 8 & $\begin{array}{c}\text { Tensile Property with beating } \\
\text { degree of 300 ml CSF }\end{array}$ & $\mathrm{Nm} / \mathrm{g}$ & 5.3 & \\
\hline
\end{tabular}

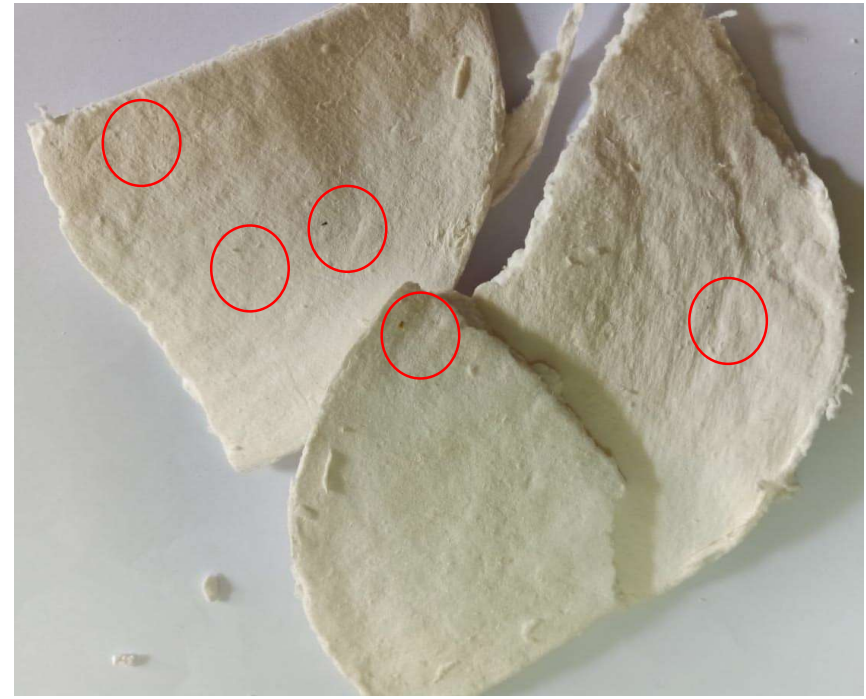

\section{FT-IR Analysis}

Fig.-3: Cellulose Pulp of Durian Peel and Some Visible Dirt (Red Circle)

Durian peel fiber consists of lignocellulose, this means it has several components, i.e. cellulose, hemicellulose, and lignin. Cellulose is constructed by D-glucopyranose units. Hemicellulose is constructed by three kinds of sugar, i.e. D-xylose, D-glucose, and mannose, the lignin is constructed by phenyl propane unit. This unit categorized as aromatic compounds, i.e. guaiacyl, syringyl, and phenyl propane (Fig. -5$){ }^{28}$

Typical band of lignin was found in the range of $1500-1600 \mathrm{~cm}^{-1}$, specifically at $1616 \mathrm{~cm}^{-1}$, it identified as aromatic $\mathrm{C}=\mathrm{C}$ vibration. Another band was found at 1830 and $1730 \mathrm{~cm}^{-1}$ that referred to the vibration of methoxy $\left(\mathrm{O}-\mathrm{CH}_{3}\right)$ and aromatic $\mathrm{C}=\mathrm{C}$ vibration. ${ }^{28,30,31}$ But these bands were not found in the FT-IR spectrum of cellulose pulp (Fig.-4), this result indicated the delignification was successfully removed the lignin, also the xylose band around $1765-1715 \mathrm{~cm}^{-1}$ that identic to the presence of hemicellulose was not found. It is believed the alkalization treatment successfully cut the hemicellulose chain. 
RASĀYAN J. Chem.

Vol. 13 | No. 3 |1767-1776| July - September | 2020

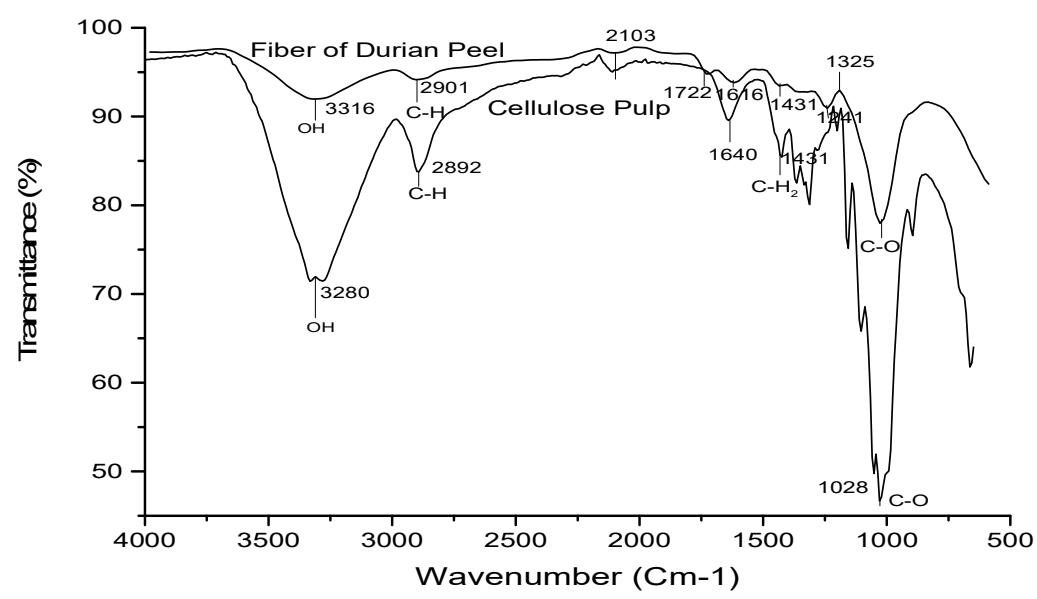

Fig.-4: FT-IR Spectra of Durian Peel Fiber and Cellulose Pulp<smiles>OC[C@H]1O[C@H](O)[C@@H](O)[C@H](O)[C@@H]1O</smiles>

a-d-glucose

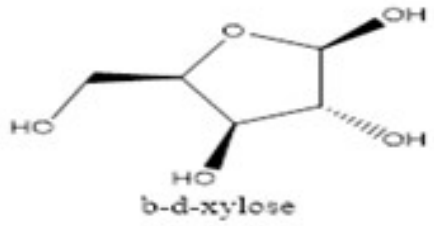

(I)<smiles>O=C(O)[C@H]1O[C@H](O)[C@@H](O)[C@H](O)[C@@H]1O</smiles>

b-d-glucuronic acid

(II)<smiles>CCCc1cc(OC)c(Br)c(OC)c1</smiles>
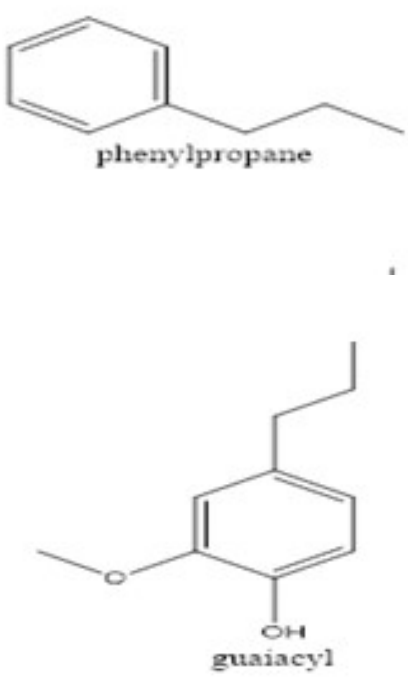

(III)

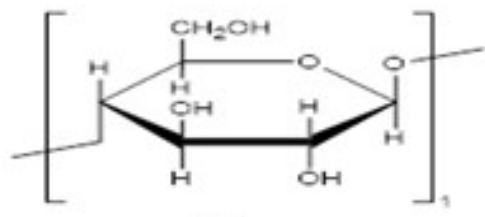

cellulose

(IV)

Fig.-5: (I) D-Glucose, D-Xylose, (II) D-Glucoronic Acid, Phenylpropane, (III) Syringyl, Guaiacyl, (IV) Cellulose 1772 
RASĀYAN J. Chem.

Vol. 13 | No. 3 |1767-1776| July - September | 2020

Table-3: Functional Group of Durian Peel Fiber and Cellulose Pulp

\begin{tabular}{c|c|c}
\hline \multicolumn{2}{c|}{ Wavenumber $\left(\mathrm{cm}^{-1}\right)$} & \multirow{2}{*}{ Functional Group } \\
\hline Fiber & Cellulose Pulp & O-H stretching \\
\hline 3316 & 3280 & C-H stretching \\
\hline 2901 & 2892 & Unconjugated C-O of Xylan \\
\hline 1722 & - & Conjugated C-O \\
\hline- & 1640 & C-Ph vibration \\
\hline 1616 & - & C-H ${ }_{2}$ scissoring \\
\hline 1431 & 1431 & Cl-O vibration of syringyl and Guaicyl \\
\hline 1325 & & C-O-C stretching of aryl-alkyl ether \\
\hline 1241 & - & C-O and C-O-C stretching of $\beta$-glycoside \\
\hline 1025 & 1028 &
\end{tabular}

\section{Morphological Analysis}

Figure-6a showed the image of morphological surface of durian peel cellulose pulp. The image showed the durian peel cellulose pulp as a long fiber. Many pores also can be found on the fiber surface. This micrograph has a different result with the untreated fiber of durian peel (Fig.-6b). The untreated fiber has a rough surface. This result confirmed a significant result of acid hydrolysis, alkalization, and bleaching treatments. Those treatments also can remove the presence of amorphous region on the cellulose surfaces. The success of treatment also can be seen from the diameter size of fiber, durian peel pulp has an average diameter of $12.41 \mu \mathrm{m}$. Normally, the cellulose pulp will have a diameter in the range of 2-20 $\mu \mathrm{m} .{ }^{32}$

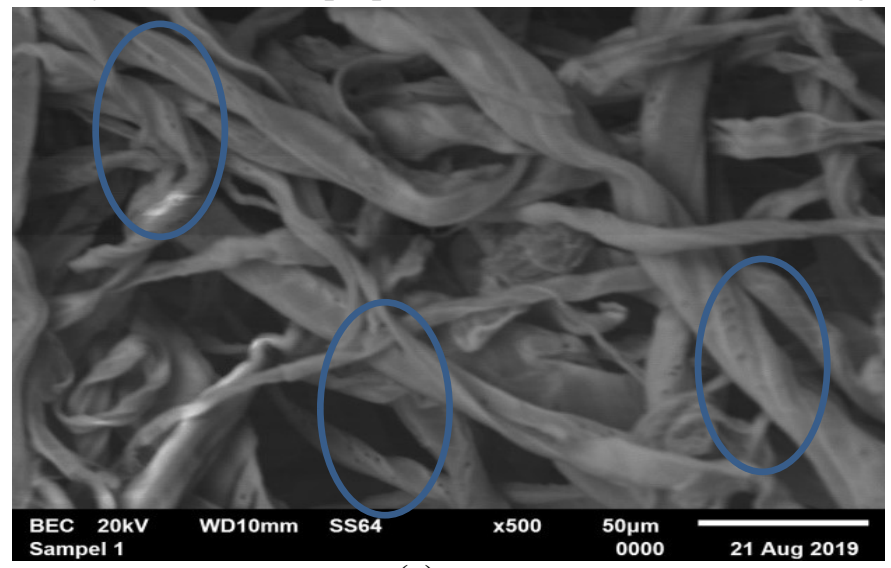

(a)

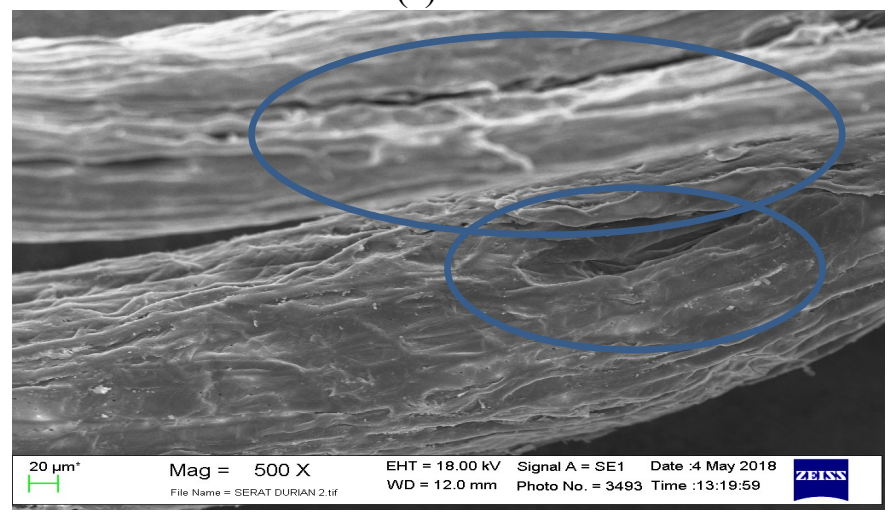

(b)

Fig.-6 : Scanning Electron Micrograph 500x (a) Cellulose Pulp(b) Durian Peel Fiber

Those three have showed a positive result to the physical properties of durian peel fiber. This treatment can be assumed that able to improve the defibrillation of fiber by detaching the process of lignin and hemicellulose. Defibrillation enhances the possibility of fiber having a smaller diameter size. The presence of $\mathrm{NaOCl}$ and hydrogen peroxide during the bleaching treatment has a big role to remove the lignin by oxidizing lignin into carboxylate or carbonyl. ${ }^{15,33,34}$ 
RASĀYAN J. Chem.

Vol. 13 | No. 3 |1767-1776| July - September | 2020

\section{XRD Analysis}

Crystallographic of durian peel fiber and cellulose pulp was shown in Fig.-7, which has a crystallinity index of 47.07 and $60.68 \%$, respectively.

The crystallography (Fig.-7) of pulp is significantly different from the untreated fiber. This can be indicated that the pulping process can improve the crystallinity degree removing amorphous region that originated from hemicellulose and lignin.

\section{Thermal Analysis}

Based on the Fig.-8, the degradation process was done through 2 steps, i.e. dehydration and degradation. Dehydration and degradation were confirmed in the range of $60-140$ and $250-450^{\circ} \mathrm{C}$, respectively. Degradation involved several reactions, i.e. decarboxylation, depolymerization and decomposition of glycoside units and the formation of ash as the residue. At $200^{\circ} \mathrm{C}$ the durian pulp has lost the weight up to $7.9 \%$ due to dehydration of pulp into de hydrocellulose. At $400^{\circ} \mathrm{C}$ durian pulp has lost the weight up to 91.7 due to degradation that involving depolymerization. DTG curve showed a single peak at $350^{\circ} \mathrm{C}$, this peak can be associated to the degradation of hemicellulose. . $^{19,30,35,36}$ The presence of acetyl group in hemicellulose cause the degradation undergoes at the lowest temperature than cellulose and lignin.

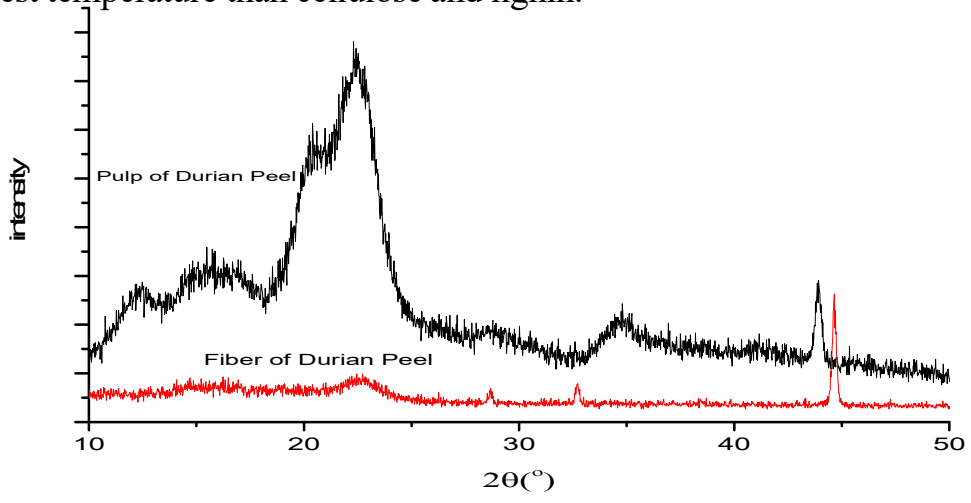

Fig.-7. X-ray Diffractogram of Durian Peel Fiber and Cellulose Pulp

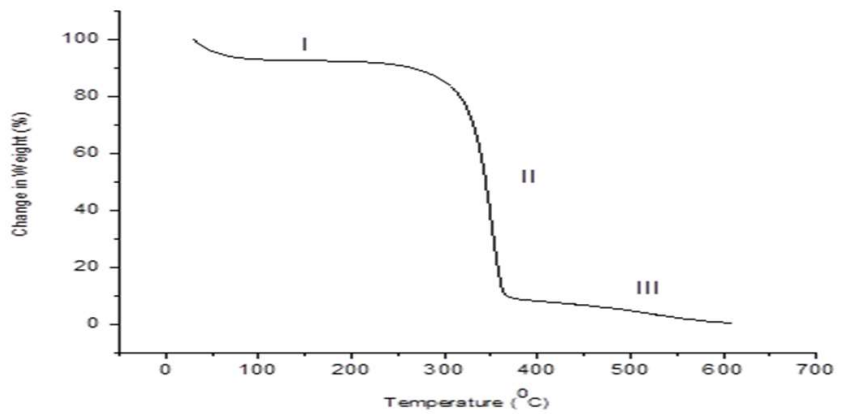

(a)

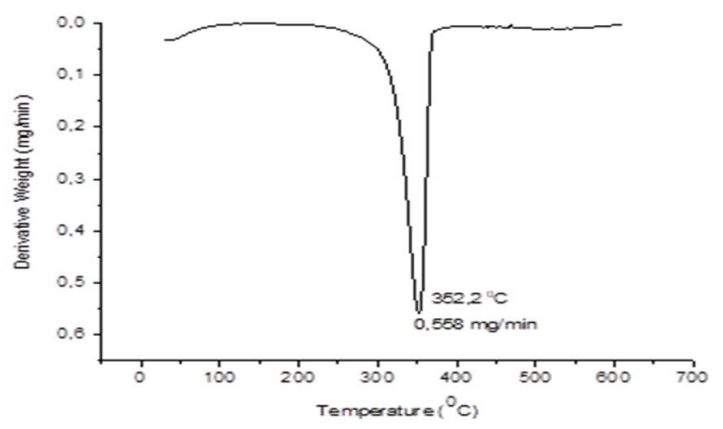

(b)

Fig.-8: Thermogram of Cellulose Pulp,(a) TGA; (b) DTG 
RASĀYAN J. Chem.

Vol. 13 | No. 3 |1767-1776| July - September | 2020

\section{CONCLUSION}

The result of this study showed that durian peel fiber can be used as an alternative for cellulose pulp production. The obtained cellulose pulp was classified into Leaf Bleached Kraft Pulp (LBKP) based on SNI 6107. The crystallinity index of durian cellulose pulp is higher than the untreated fiber due to the hydrolysis, alkalization, and bleaching process.

\section{ACKNOWLEDGEMENT}

The author thanks supervisor and co-supervisor for the help and kindness for the guidance to finish the study entitled "PREPARATION AND CHARACTERIZATION OF CELLULOSE PULP FROM DURIAN PEEL". Also, thanks go to LPDP (Lembaga Pengelola Dana Pendidikan) Indonesia for the financial support to perform this study.

\section{REFERENCES}

1. S. Ouajai, A. Hodzic, and R.A. Shanks, Journal of Applied Polymer Sciences, 94, 2456(2004). DOI: $10.1002 / a p p .21191$

2. W. Wang, P. Zhang, S. Zhang, F. Li, J. Yu, and J. Lin, Journal of Carbohydrate Polymers, 98, 1031 (2013), DOI:10.1016/j.carbpol.2013.06.076

3. S. Silviana and A. Subagio, Rasayan Journal of Chemistry, 12(3), 1470(2019), DOI: $10.31788 /$ RJC.2019.1235240

4. F.K. Siregar, D.Y.N.Y Muis, and D.Y. Kaban, Rasayan Journal of Chemistry, 12(2), 554(2019), DOI: $10.31788 /$ RJC.2019.1225126

5. I.P. Mahendra, B. Wirjosentono, H. Ismail and J.A. Mendez, Rasayan Journal of Chemistry, 12(2), 635(2019), DOI: 10.31788/RJC.2019.1225089

6. L. Zheng, C. Zhua, Z. Dang, H. Zhang, X. Yi, and C. Liu., Journal of Carbohydrate Polymers, 90(2), 1008 (2012), DOI: 10.1016/j.carbpol.2012.06.035

7. R. Mahalakshmi, K. Preethi, D. Kalaiselvi, M. Manjuladevi, K. Karthik and R. Marimuthu Rasayan Journal of Chemistry, 12(1), 245(2019), DOI:10.31788/RJC.2019.1215001

8. P. Rousu, P. Rousu and J. Anttila, Journal of Resources, Conservation and Recycling, 35(1-2), 85 (2002), DOI:10.1016/S0921-3449(01)00124-0

9. L.Y. Mwaikambo and M.P. Ansell, Journal of Applied Polymer Science, 84, 2222(2002), DOI: $10.1016 /$ j.indcrop.2017.11.016

10. R. Dewi and A. Putri, International Journal of Innovative Research in Advanced Engineering, 3 (03), 28(2016), DOI:10.6084/M9.Figshare.3504209.V1

11. P. Penjumras, R.B.A. Rahman, R.A. Talib and K. Abdan, Journal of Agriculture and Agricultural Science Procedia, 2, 237(2014), DOI:10.1016/j.aaspro.2014.11.034

12. P. Penjumras, R.A. Rahman, R.A. Talib, and K. Abdan, International Journal on Advanced Science, Engineering and Information Technology, 5 (5), 343(2015), DOI:10.18517/ijaseit.5.5.574

13. K.Y. Foo and B.H. Hameed, Journal of Biomass and Bioenergy, 35(7), 2470(2011), DOI: 10.1016/j.biombioe.2011.04.004

14. P. Rachtanapun, S. Luangkamin, Tanprasert, K. and Suriyatem, R., LWT - Food Science and Technology, 48 (1), 52(2012), DOI:10.1016/j.lwt.2012.02.029

15. W.P.F. Neto, H.A. Silvério, N.O. Dantas and D. Pasquini, Journal of Industrial Crops and Products, 42, 480(2013), DOI: 10.1016/j.indcrop.2012.06.041

16. J. Lin, L. Yu, F. Tian, N. Zhao, X. Li, F. Bian, and J. Wang., Journal of Carbohydrate Polymers, 109, 35(2014), DOI:10.1016/j.carbpol.2014.03.045

17. S. Gharehkhani, E. Sadeghinezhada, S.N. Kazi, H. Yarmanda, A. Badarudina, M.R. Safaei, and M.N.M. Zubir, Journal of Carbohydrate Polymers, 115, 785(2015), DOI: 10.1016/j.carbpol.2014.08.047

18. D.W. Chae, K.R. Choi, B.C. Kim and Y.S. OH, Textile Research Journal, 73 (6), 541(2003), DOI: $10.1177 / 004051750307300613$

19. F. Fahma, S. Iwamoto, N. Hori, T. Iwata and A. Takemura, Journal of Cellulose, 17(5), 977(2010), DOI: $10.1007 / \mathrm{s} 10570-010-9436-4$

20. S. Sharma, S.S. Nair, Z. Zhang, A.J. Ragauskas and Y. Deng, Journal of Royal Society of Chemistry 1775 
RASĀYAN J. Chem.

Vol. 13 | No. 3 |1767-1776| July - September | 2020

Advances, 5(77), 63111 (2015), DOI:10.1039/C5RA09068G

21. R. Lubis, S.W. Saragih, B. Wirjosentono, and Eddyanto, In Proceedings The 3rd International Seminar on Chemistry, Surabaya, Indonesia, 020069-1(2018), DOI:10.1063/1.5082474

22. C. Xu, S. Zhu, C.Xing, D. Li , N. Zhu , and H. Zhou., PLoS One, 10(4), 1(2015), DOI: 10.1371/journal.pone. 0122123

23. S. Indran and R.E. Raj, Journal of Carbohydrate Polymers. 117, 392(2015), DOI: 10.1016/j.carbpol.2014.04.051

24. V.A. Barbash, O.V. Yaschenko, O.M. Shniruk and V.O. Kovalchuk, Journal of Nanoscale Research Letters, 195, 497(2017), DOI:10.1186/s11671-017-2001-4

25. K. Mundsinger, A. Müller, R. Beyer, F. Hermanutz, M.R. and Buchmeiser, Journal of Carbohydrate Polymers. 131, 34(2015), DOI:10.1016/j.carbpol.2015.05.065

26. M. Jabli, N. Tka, K. Ramzi and A. Saleh, Journal of Molecular Liquids, 249, 1138(2018), DOI: $10.1016 /$ j.molliq.2017.11.126

27. W. xu, Textile Research Journal, 73 (5), 433(2003), DOI:10.1177/004051750307300510

28. J.I. Morán, V.A. Alvarez, V.P. Cyras and A. Vázquez, Journal of Cellulose, 15(1), 149(2008), DOI: $10.1007 / \mathrm{s} 10570-007-9145-9$

29. E. Vismara, G. Gastaldi, A. Valerio, S. Bertini, C. Cosentino and G. Eisle, Journal of Materials Chemistry, 19(45), 8678(2009), DOI: 10.1039/b911610a

30. Y. Liu, D. Thibodeaux, G. Gamble, P. Bauer and D. VanDerveer, Journal of Applied Spectroscopy. 66 (8), 983(2012), DOI: 10.1366/12-06611

31. K. Das, D. Ray, N.R. Bandyopadhyay and S. Sengupta, Journal of Polymers and the Environment, 18(3), 355(2010), DOI:10.1007/s10924-010-0167-2

32. L. Yu, J. Lin, F. Tian, X. Li, F. Bian and J. Wang, Journal of Materials Chemistry . A, 2(18), 6402 (2014), DOI:10.1039/c4ta00004h

33. D. Ciolacu, F. Ciolacu and V.I. Popa, Journal of Cellulose Chemistry and Technology, 45 (1-2), 13 (2011), DOI:10.1163/156856198X00740

34. S.J. Chun, S.Y. Lee, G.H. Doh, S. Lee and J.H. Kim, Journal of Industrial and Engineering Chemistry, 17(3), 521(2011), DOI:10.1016/j.jiec.2010.10.022

35. W. Stelte, W. and A.R. Sanadi, Industrial and Engineering Chemistry Research. 48 (24), 11211 (2009), DOI:10.1021/ie9011672

36. C. V. Abiaziem, A. B. williams, A. I. Inegbenebor, C. T. Onwordi, C. O. Ehi-Eromosele and L. F. Petrik, Rasayan Journal of Chemistry, 13(1), 177 (2020), DOI:10.31788/RJC.2020.1315328

[RJC-5807/2020] 